\title{
Role of Cultural Heritage in the Development of Gastronomy Tourism in the Rural Area: Case of the Vipava Valley
}

\author{
Anja PIPAN, Aleš GAČNIK* \\ University of Primorska, Centre of Gastronomy and Wine Culture, Faculty of Tourism Studies Turistica, \\ Obala 16a, 6320 Portorož, Slovenia
}

\begin{abstract}
Food is a reflection of natural resources, social, economic and cultural development, which is why specific features develop in cuisine, nutrition and technology. Dishes become typically territorial because of the terroir that shapes the characteristics of the local dishes and ingredients. When planning a proper gastronomic tourism offer for the requirements of the modern tourist, it is essential to base the gastronomy on everything that is given to us by both modern cultural influences and those from the past. The research focuses on gastronomy and cuisine as interpretive tools for learning about the cultural heritage of the Vipava Valley. Based on existing theoretical findings, we examined the potential of gastronomic tourism and the role of heritage in it through semi-structured interviews with experts from various fields related to Vipava gastronomy or material and non-material cultural heritage. The findings of the interviews were confirmed by analyzing three cases from the local environment. Consolidation and upgrading of gastronomy tourism of the Vipava Valley primarily depends on the stimulating economic environment, respect for the heritage itself and individual innovations. Sustainable development of the destination is based on a strong identity of the local people and is connected with rich natural resources and the heritage of producing and processing of safe, seasonal and high-quality raw materials. The research has confirmed the great role of nature in shaping the cultural heritage in the rural areas.
\end{abstract}

Key words: Gastronomy, Tourism, Rural development, Agriculture

\section{INTRODUCTION}

The acquisition of the title "Slovenia - European Region of Gastronomy 2021" and the exposure of gastronomy as the main theme of Slovenian tourism for the years 2020 and 2021 are fundamental for focusing on possibilities of rationalizing the inclusion of heritage elements in programs and activities of gastronomy tourism. The acquired title is a great developmental opportunity for the international recognition of Slovenian gastronomy and should not be understood as a promotional tool, but first of all as a developmental project of the country. That is why the Slovenian Tourist Board has chosen gastronomy as the main topic of Slovenian tourism in 2020 and 2021. The national Strategy for the Sustainable Growth of Slovenian Tourism 2017-
2021 includes the integration of cultural heritage into tourism offer which is the very core of state identity. The strategy of the four key products, with a strong impact on the revenue and image of a state, highlights both - gastronomy and culture. Among the three products with a small or medium impact on the state revenue and image, it also highlights rural tourism. The regional diversity, variety and presence of heritage are recognized as key elements of sustainable and boutique tourism in Slovenia (Government of the Republic of Slovenia, 2017).

Food is a cultural experience which represents traditions, stories and symbols. Food defines a gastronomy space and can be used in a lot of forms and interactions with tourism in a particular area or region (Ashleigh, Parkb, Sangkyun, and Yeoman, 2018). 
Local gastronomy has a central role as a tourist attraction and is one of the main motives and objectives when we visit a tourist destination. On the other hand, tourism industry is one of the key tools for preservation, communication and development of gastronomy heritage. It is associated with local people and their culture, migration, rural traditions, agricultural knowledge and technologies. The local terroir is crucial for rural tourism development, when food and gastronomy are no longer of secondary importance, but it is a key attraction, primary or secondary motive for a tourist's arrival at a destination. Tasting food at a destination does not merely satisfy the need for food, but also represents an experience of the local culture and interaction with their hosts (Bjork-Galvez, Lopez-Guzman, Cordova-Buiza and MedinaViruel, 2017). Gastronomy tourism must be understood as a medium of communication and international recognition of gastronomic regions, destinations, states (Gačnik, 2012). Sustainable development and culinary tourism both signify sustainable management of cultural resources. To be more exact, food is considered an intangible heritage, but it is produced, as well as consumed, within certain geographic areas (Ashleigh et al., 2018).

In the ever-increasing competition between destinations, gastronomy is recognized also from the UNWTO as an important medium for heritage and heritage tourism communication and promotion(UNWTO,2017) Gastronomy tourism has been identified as one of the best ways to strengthen and consolidate specifics of tourist destinations. For travelers and tourists, it is increasingly important that everything is connected with the gastronomic culture of the places they visit. Gastronomy is becoming an increasingly important factor of the tourist destinations development and state visibility (Gačnik, 2012) and as a part of a national culture, enables any country, even a small country or province, to present a number of features that are among its distinctive advantages and specifics (Milfiner and Lebe, 2008). Milfelner and Lebe (2008) carried out a quantitative research and found out that the tourists who come to Slovenia are very keen to learn about the cultural heritage through local gastronomy. Nowadays, we learn through food and gastronomy about our hosts, heritage and culture, the environment, economic commitment, social relationships, and religion in local and regional areas. Therefore, food is not associated only with dishes and flavors, but is also an important motive for travel and integration of people (Bogataj, Škufca Adlešič, Renko, Zmrzlikar and Kejžar, 2018). Customs, habits and the way of life have an impact on the environment. The dishes are linked with the seasons and menus vary according to the occasion: everyday life, holidays and celebrations, farm work specifics and opportunities (»šagra«- celebration festivities of a church patron / saint, "god" - name day, a birth, a wedding, etc.) (Merljak, 2016).

"The linkages between food and tourism provide a platform for the transmission of culture, local economic development, sustainable practices and food experiences, which help to brand and market destinations, as well as support local traditions and diversity (UNWTO, 2015)."

Food is an extremely important part of the tourism system; it is a very basic necessity, and its quality plays an important role in the overall tourist experience. Food refers to the physical fare consumed by people, but when we are talking about the culinary smells, sights, sounds, and eating practices of people or a region, as well as culinary routes, sites, and landscapes, we are referring to "foodways". This includes cooking methods, recipes, ingredients, dining customs, social connotations, food-related rituals and festivals, hunting and farming traditions, and family ties. »Cuisine is, without a doubt, one of the most salient and defining markers of cultural heritage and tourism (p.99, Timothy, D. \& Amos, R, 2013).

The methods of food acquisition, its preparation and consumption are extremely important elements of cultural heritage. Over the centuries, farmers have become accustomed to cultures that succeed best in a local environment. The latter became an important factor, where agricultural products and foodstuffs contribute to regional specialties and national dishes (Timothy, 2016). The local cuisine presents the manifestation of the destination's intangible heritage and through consumption tourists can gain a truly authentic cultural experience (Okumus, Okumus and McKercher 2005). Gastronomy can also indicate the character of a society and its mentality, especially if it is recognized by the local population (Bessière, 1998). The basis for the local community development in rural areas is a respect of local people towards their cultural heritage, natural resources and their own identity. ICOMOS - Slovenian National Association for the Monuments and the Monument Protection Areas (2003) emphasizes the recognition of the complex natural and cultural heritage sites as an essential starting point for the value of the creative economy and the development of the area.

The aim of the research is to identify cultural heritage and tourism elements that will contribute to the development of gastronomy tourism in the Vipava Valley, with the preassumption that more active inclusion of heritage attributes in gastronomy tourism offer and dynamic strategic actions will bring positive results to stakeholders in tourism industry and to agriculture in the Vipava Valley. We analyzed gastronomy as a potential interpretational tool for presenting heritage and defined its role in the development of gastronomy tourism in the Vipava Valley. All that with the intention to encourage strategic development of a destination in which gastronomy would become a central interpretive element.

Slavica Plahuta (2002) describes the area of the Vipava Valley and Goriška region as open to foreign influence. The latter is the main reason for such a diverse cuisine, because of all the armies that have passed through the area and all the locals who have travelled around the world and then returned. The dishes are a result of natural conditions, historical and social circumstances, the influences of neighboring landscapes and interplay (Plahuta, 2002b, p. 9). It is hard to define what constitutes the gastronomy identity and culinary image of the Vipava Valley. The locals always took the recipes of the dishes they liked and adapted them based on the ingredients available to them (Gomišček, 2011). 


\section{MATERIAL AND METHODS}

The empirical part of the research includes the following qualitative methods: interview, field research work and method of observation. The main objectives of the research are:

1. What is the potential of cultural heritage for gastronomy tourism development in the Vipava Valley area?

2. Which types of heritage influence the gastronomic identity and the gastronomy tourism of the Vipava Valley?

A semi-structured interview was selected as the main measuring instrument, for which a theoretical part of heritage and tourism potential analysis, mainly related to gastronomy, heritage and tourism, was used as the basis. The questionnaire consisted of questions divided into three groups: tourism, heritage and other developmental attributes of the Vipava Valley. We answer the main research questions by categorizing our data into concepts, properties and patterns.

The second part of our research involves observation and fieldwork. On the basis of preliminary analysis in the theoretical part of the Vipava Valley research and information obtained from the interviewees, we sought elements that support the purpose of the study. Previously defined loose categories helped us in this. The observation was partly held in a structured way, as we have previously stated the light categories that followed objectives and research questions.

The second method involves an observation of three case studies with potential to contribute to the research results and to the objectives of the assignment. Our field research work interest was focused on the following questions: the collective identity, stories of objects, what are their direct and indirect connections to gastronomy, how they explained their stories etc. On these bases, we recognized the gastronomic and tourist potential of objects, collections and museums. The results of the interviews were crucial to achieving the objectives of the assignment, but the method of observation substantially complemented the direction of the research.

From the results of the research, we chose to use a pyramid model. The foundation for the model was a determination of gastronomic pyramid by dr. Janez Bogataj in the Development Strategy of Gastronomy in Slovenia (2006). A gastronomic pyramid by dr. Bogataj consists of 3 parts - the first one

\footnotetext{
${ }^{1}$ Interviews were conducted with: Mirjana Bužanin (manager of the Vipava Valley local products store, Darovi Vipavske in the Vipavski križ), Slavica Plahuta (M.Sc. in history and former director of Museum Goriški muzej, author of research of the culinary traditions in Goriška region), Jasna Fakin Bajec (ethnologist and professor of history, employed at the ZRC SAZU research station in Nova Gorica), ROD Development Agency (one of the key players in the development of sustainable tourism in the Vipava Valley), Matej Tomažič (chef, owner and creator of the Majerija house in Slap, Vipava Valley), Boris Blažko (Curator of the Museum Goriški muzej and president of the Association Doli Lokavec).

2 The method includes - Šturje gourmands (»Šturske gurmanke» - a group organized within the elementary school Šturje in Ajdovščina, Vipava Valley), Vipava Wine Museum in Vipava (Museum Goriški muzej, located in Lanthieri castle in Vipava), three ethnological collections: Šrgalova hiša (Kovk), Kebetova hiša (Vipava) and Batičeva hiša (Lokavec).
}

represents the dishes of Slovenian gastronomy, the second one shows the most recognizable dishes and the last and the widest part presents the richness of culinary and gastronomic heritage.

\section{RESULTS}

Based on the results, we have created various developmental aspects of the role of cultural heritage in gastronomy tourism in the rural areas (Vipava Valley).

\section{Cultural heritage aspect and potentials of the rural gastronomy tourism development}

Plahuta (personal communication, 19 November, 2018) claims that food is a reflection of natural resources, social, economic and cultural development. Therefore, specialties are reflected in cuisine, food and technology. The gastronomy and the dishes have also been shaped, in a large extent, by the valley's transit role, which has been reflected throughout history in the blending of nations and cultures. This is why the food is so diverse, but basically not authentic. It's a mixture of Slavic influences (venison, forest raw materials) with the Roman culture of the native people (wine, milk, olive oil), emphasizes Plahuta, who adds that the Roman culture was mixed with Arabic, where pasta and confectionery come from.

With the heritage giving uniqueness to the offer, as well as some added value, this makes a winning combination, because it also extends its values. »The heritage itself with no added value is more or less empty." (Bužanin, personal communication, 15 November, 2018). Bužanin describes the experience of a visitor in Vipavski križ, a small medieval town, unique and special because of heritage, but yet offers something that complements it. Visitors can absorb some of the energy and take some charm of the place just by sitting and sipping wine. She also believes that there are many stories throughout the villages of the Vipava Valley ready to be presented.

Blažko sees the greatest potential in valuation of water in all possible forms, from food to architecture (Blažko, personal communication, 5 December, 2019). The ROD sees a big developmental attribute in rich industrial heritage, most of which comes from the agricultural and food sectors. Because of this fact, there is so much knowledge in the area, so the valley should have a centre for gastronomy. »Certainly, openness has contributed to our identity, both in cuisine and in general." (ROD, personal communication, 14 January, 2019).

Developmental opportunities are just as widely open for the Wine Museum in Vipava. The basic idea behind it is to become a starting point for the tourists visiting the region. Gastronomy is currently not presented in a museum, for which a further cooperation of different professions and stakeholders in the region would be required. The museum incorporates the old with the new, in line with this Koloini (curator of museum) highlighting that » ...new stuff has grown out of the old (Koloini, personal communication, 22 December, 2018).« 
Jasna Fakin Bajec generally recognizes heritage as a generator of destination development, a generator of gastronomy tourism along with the creative industries, but also emphasises that heritage and tradition are still a developing category. Chef Tomažič believes that the food and the wine are just an upgrade to the natural and cultural sights of the Vipava Valley and that the gastronomy tourism is an important branch of tourism. According to him, wine and cuisine are the reason for the influx of tourists in the Vipava Valley. Tomažič also believes the winemakers and chefs should participate in the process of creating an offer that is of the highest quality and territorial characteristic. He finds it important to pass a message of the local mentality to the guests when talking about the gastronomy. Seasonality, food diversity, special occasions or celebrations are emphasized. He suggested concrete activities as an opportunity to promote the area known as the »Mineštra Valley« (seasonal stew made from seasonal vegetables), since it is actually found on the table of the local people almost daily. "... and the guest who comes knows that they are in the Vipava Valley, and I must eat mineštra myself before going somewhere« (Tomažič, personal communication, 1 February, 2019).

Bužanin emphasizes the networking between regions: »There should be more networking and cooperation between providers and different stakeholders. The tourists will be more satisfied and will experience more once they have the big picture of the whole offer.« (Bužanin, personal communication, 15 November, 2018). Upgraded promotional activities would be a step in the right direction, but the locals first need to embrace the concept and the direction in which tourism in the Vipava Valley is headed. However, if the Vipava Valley wants to be recognized as a gastronomic and wine region, it must define the right profile of travelers and tourists, the targeted public. Consequently, all activities must be carried out with the appropriate approach, respectful towards the heritage and history, emphasizing them at the same time.

\section{Agricultural and natural effects}

An important impact on the gastronomy of the Vipava Valley is the production of its own ingredients and their use in cuisine. The common thread in the gastronomy of the valley are clearly natural resources. Plahuta highlights the importance of soil and the climate, which leads to specific samples of ingredients, naming them by organoleptic features, which is how the dishes become characteristically territorial.

The main features and best attributes of Vipava Valley's gastronomy are that the ingredients are locally grown, pesticide free and have a strong organoleptic content (Plahuta, personal communication, 2018). The area has a long vegetation season, which lasts from April to November, and seasonality of ingredients is also reflected in the gastronomy. The latter is also taken into account by the catering providers and guests can tell just by looking at the plate that the ingredients are from the immediate surroundings. Concept »kilometer 0 « was mentioned by several interviewees, in addition, the ROD developmental agency also highlights a long vegetation period in an area that is also reflected in cooking. Tomažič claims that it is important to emphasize its uniqueness in nature and its features: vineyards and cultural landscape, as well as the cultural and historical sites. The area is on the border between the Mediterranean climate and its food and wine culture, and on the other hand, between the central and continental climate and culture.

Another common feature of research on ethnological collections is the dependence of living arrangements, culture and the character of gastronomy on nature. An example is "Šrgalova hiša" on Kovk (Trnovo plateau) where they have, due to lack of conditions for farming, practiced trading with goods, which extends beyond the Vipava Valley. Activated carbon, limestone and ice have got a variety of ingredients. Plahuta says, in the same spirit, that the traditional gastronomy of our ancestors has always included fish dishes, due to the proximity of the sea and commerce, but also due to the enormous resources of freshwater fish species throughout the valley. In another example of »Kebetova hiša«, we recognize the importance of cultivating local ingredients. Even though the owners were educated and reasonably wealthy, despite being in possession of fields and woods, they were actually involved in agriculture.

Perhaps the most important and deep-rooted tradition in the Vipava Valley is the heritage and culture of winemaking. All the interviewees stress the importance of wine. Tomažič (2019) sees the heritage of wine production as one of the main factors for the guests to return to the destination. Both Tomažič and Plahuta also underline the importance of wine culture and its traditional use in cooking, Bužanin detects wine as a key factor in gastronomy and also as the most important element in the tourist offer, but also stresses the importance of the development of tourism infrastructure for the successful marketing of this heritage element. Indigenous grape varieties of the Vipava Valley still remain an untapped potential. There are also some traditional crafts related to viticulture, such as »barrel-making«, which are waiting to be rediscovered in the area (Koloini, personal communication, 22 December, 2018). The greatest influence on all of the knowledge and quality of wine in the valley was given by Matija Vrtovec and his book "Vinoreja (viticulture and winemaking) from the 19th century, which is still used today by many big winemakers of the Vipava Valley (ROD, personal communication, 14 January, 2019).

\section{Promotion and tourism development through personal identity}

Tourism, however, can be a field which helps to preserve heritage and cultural habits. Raising awareness of its own cultural heritage and enhancing its values could also be achieved through the involvement of young people in different activities. High school students, for example, are at a point in their life when they are creative and at the same time critical to a variety of topics. Jasna Fakin Bajec points out the missing initiatives in the system and suggests that heritage must be presented as a generator of regional development, gastronomy tourism and creative industries. She suggested activities and encouragement from municipal authorities to young people. The ROD points out Faladur (a Wine bar \& shop in Ajdovščina) and their tremendous work with 
children. Within a variety of workshops, children are able to work on a garden, pick up products and then cook them. Children collaborating in the process can see a beautiful story, which could stimulate them to carry out such activities in the future (ROD, personal communication, 14 January, 2019). Petra Ušaj is the mentor of Šturje gourmets, one of the researcher's case study. She highlighted the main purpose of their activities; knowledge and awareness of the importance of preserving its own culinary heritage. Activities are being held at the Elementary school Šturje in Ajdovščina and Šturje gourmets could be an example of how development of the culinary arts and also indirectly gastronomy tourism is approached from a different perspective but with a variety of developmental possibilities. »In the process of preparing food for themselves, children gain a certain attitude and respect towards it. In this way, the new knowledge is spread further, among their acquaintances and friends." (Ušaj, personal communication, 17 February, 2019). A deliberate introduction of food content into the school program, from the beginning of the recently established Elementary school Sturje, is achieving the intended purpose and they are futher raising awareness on healthy eating.

Plahuta sees tourism as a tool to emphasize the unique identity of the Vipava Valley, describing it as a mixture of fusion. Jasna Fakin Bajec thinks it is necessary to find a way to present the tradition in an innovative way, in order to add value to tourism. She repeatedly emphasized the need for more collaboration between the professions and between different communities in society. Blažko also points out that the story providers are people, living in a community and that the idea must be born and developed from them and only then potentially be upgraded from a profession. Plahuta also claims that the traditional local food (methods of preparation, taste and cultural heritage aspect side of the story) is one of the fundamental components of a local identity and serves as a component in the presentation of ways of local living.

Both Fakin Bajec and Bužanin emphasize the role of public organizations and municipalities in presenting the heritage values and consequently, developing tourism. Bužanin believes that it is important for the public to accept the increasing development of tourism (in Vipavski križ). By systematically presenting the values of the heritage and its developmental possibilities, we can influence a stimulative economic environment (Fakin Bajec, personal communication, November, 2018).

\section{DISCUSSION}

We chose to design three pyramid models from the results of the research. We chose them because of its positive experience in the case of creating a gastronomic pyramid of Slovenia (the Development Strategy of Gastronomy in Slovenia, 2006). In our research, we have developed three pyramid models; a pyramid model of heritage elements, a pyramid model of developmental approaches to gastronomy tourism in the Vipava Valley and a pyramid model of traditional Vipava Valley dishes. Only the last one will be presented in detail. The shape of the pyramid allows us to discover the opportunities of untapped potential in the gastronomic tourism of the Vipava Valley. We also took into account their ability for interpretation in tourism.

\section{The pyramid model of traditional dishes in Vipava Valley}

For this model, we use the information that we have gained in the theoretical part of the research and from the results of the empirical part. The richness of Vipava Valley's cuisine is extensive and would require a specific study on its own. Traditional dishes used in pyramidal model are dishes named from interviewees in semi- structured interviews from the research presented in this article.

At the bottom, the widest part of the model, we chose the typical dishes, which can be a source of ideas, using the least amount of potential too. In the middle section we chose a set of dishes, which, according to the results of the research, are the ones that have potential of representative dishes. At the top of the ranked elements are the most representative dishes of the Vipava Valley. We focus on the final products - dishes, but have decided to list some of the ingredients which were outstanding and often mentioned during the research. The dishes we included in the pyramid model are presented in the following section:

At the top as representative elements:

wine(PlahutaandBužanin, personalcommunication,

November, 2018),

"mineštra« (a seasonal vegetable stew) (Plahuta, personal communication, November, 2018 and Ušaj, personal communication, Februar, 2019)

In the middle of the pyramid model:

- »štruklji« (Plahuta and Bužanin, personal communication, November, 2018),

- Vipava prosciutto, »bleki«, polenta (corn porridge), Vipava sausages with wine, »frtalja» (fried egg dish), "mlinci«(Plahuta, personal communication, November, 2018),

fig's coffee (Fakin Bajec, personal communication, November, 2018).

At the bottom:

- " "šnite« (fried bread soaked in eggs) (Ušaj, personal communication, Februar, 2019),

"flancati«(fried dough), "pogače« (baked bread with different toppings), bread (holiday bread also "potica', "pinca«), cooked apples, fish (for example polenovka) (Plahuta, personal communication, November, 2018), "guštnca" (variety of authentic corn) (Fakin Bajec, personal communication, November, 2018 and Ušaj, personal communication, Februar, 2019).

We have included indigenous wines and "mineštre» the seasonal vegetable stews at the very top of the pyramid model. Some very rich traditions from past with strong presence in daily life are connected with the wine culture. All the indigenous grape varieties have a lot of developmental potential, as well as integration in cuisine and gastronomic stories. "Pinela« and "zelen« deserve special mentioning, but there are also other authentic varieties with a big impact 
(klarnca, sites, pelegrin etc.). More attention needs to be paid to »rebula", domesticated variety and to all of the world's wine varieties which are feeling at home in the Vipava Valley (merlot, barbera, riesling, etc). The technology with very traditional natural maceration and "fashion« of orange (amber) wines are also important. "Mineštra« as a selected representative dish reflects a common thread of the area, factor of nature and consequently seasonality, which is very present in the Vipava Valley culinary and especially in this particular dish. In fact, the local people in the Vipava Valley eat something on a spoon every day and a lot of them are eaten on daily basis (»jota«, »ječmenovka«, "šelinka«, »mineštra«, etc).

In the middle section of the model, we can find the actual meals or products which have derived from inheritance or traditional dishes and are already made in a modern way. Particular attention should be devoted to »štruklji«, because they are very present in people's everyday lives and often as a holiday dish. Plahuta called the Vipava Valley »the land of štruklji« and also emphasizes the technology of cooking them in steam and their taste of canvas (that are traditionally cooked in). An interesting potential is also fig's coffee (coffee made from dry figs, sweet and rich in fibre, as in the past people could not afford real coffee).

At the bottom of the pyramid, we have chosen the dishes that are less known in the area and derive from different traditions, or food, which at first, due to a lack of understanding the concept of gastronomy as an evolving category, are not understood as traditional Vipava Valley's dishes. We have mostly included simple dishes that can potentially become designed in more modern dishes. From the theorethical and empirical research work, we can take the main characteristics of the dishes in the Vipava Valley: the use of olive oil and also pork lard, cooking with wine, specialties with sweet and sour combinations (»štruklji« and zucchini jam,...) and the use of fresh herbs. The use of vegetables is very common and widespread, side dishes are very simple - for example "mlinci« and »bleki« are traditional side dishes (kind of a cooked dough, sliced into pieces, similar to the Italian pasta), as well as potato. The menu usually consists of a lot of meat, most often pork, but the use of fish is very traditional and common as well.

The most obvious heritage feature that connects all of the elements in which cuisine can be justified is "fusion", a mix of various impacts, which could be a consequence of transient role of the Vipava Valley. The changeability of the relief caused a stir of cultural influences; thus, the crossing qualities of nature are also a source of diverse living conditions in the valley and consequently a diverse cuisine. Due to the tradition of agriculture and cultivation methods, domestic sourcing of ingredients is a big factor in Vipava Valley's cuisine. Seasonality and abundance of fresh and raw ingredients throughout the year can be a differential element from a marketing point of view and a starting point for innovative products. "The foundation is in everything that nature, climate and work of human hands gives us." (Plahuta, personal communication, 19 November, 2018). The most outstanding and repeatedly emphasised are the locally produced fresh ingredients and consequently the concept of »kilometer 0 «. These elements can be at the top of the activities of various disciplines and DMO organisations through a variety of incentives and awareness-raising projects that include innovation within tradition and represent a link between locally produced ingredients and health.

\section{CONCLUSION}

When discussing the development of tourism in the rural area in general, we can discuss the rural development of the Vipava Valley specifically, which has been partly caused by the development of tourism in that area. At the same time, despite several major regional centers, the entire area of the Vipava Valley could be considered rural. In general, the research confirmed the important role of nature in the creation of the cultural heritage of the whole area. The cultural heritage and heritage of gastronomy of the Vipava Valley are unique and strongly linked to the environment, nature and natural resources. The rooted tradition of agriculture, combined with the food industry and traditional crafts, have shaped the past and are strongly influencing the current way of life and culture, as well as the potential of (gastronomy) tourism development.

The main output which needs to be addressed and comes from the research results, are the required activities for gastronomy tourism development. Gastronomy can be an interpretative tool, especially useful in an area with such diverse cultural heritage and natural values. Through gastronomy (wine and food), we can strategically represent a part of our history as well as our economic and social orientation (the sustainable aspect that the region embraces, trends etc.). The impact of such an interpretation is likely to fluctuate depending on different segments, but a thoughtful development strategy can set an example for tourism development. As pointed out by Matej Tomažič, we can potentially be more successful if we deviate from the proven trends.

Gastronomy has already been recognized as the most effective tool for improving the competitiveness of a destination, and it seems to be the case in the Vipava Valley as a gastronomy tourism destination. It offers the foundation for a new understanding of luxury and boutique, through a personalized approach and offering one-of-akind experiences, advocating for authenticity, uniqueness, exclusivity, a modern understanding of heritage as a platform to foster creativity and innovation, including elements of quality surprises.

In the spirit of Slovenian tourism's focus on sustainable development and the suitability of the Vipava Valley to follow, one of the main activities is to invest in the knowledge of the people. The paper also demonstrates the importance of a strong local identity that can be built from a young age, and in the long term, such activities can pay off with future innovative products, optimizing local selfpromotion and healthy eating awareness. Such incentives could be implemented by public organizations and by integrating heritage into school and awareness programs, emphasizing the importance of heritage by focusing on the positive effects that local products and traditions add to the quality of life of the residents. It is important to expand the 
provider's knowledge and skills (including presentations of good practices, entrepreneurial workshops, communication workshops, etc.) as soon as possible. Cross-sectoral cooperation is needed in the organisation of such activities, especially between the sectors of agriculture, tourism, culture and science, and with incorporating digital marketing and modern communication methods. Moreover, such cooperation is one of the opportunities to acquire an element of cultural heritage and gastronomy to which everyone would have a positive attitude (local population and tourists). The ROD development agency suggested that because of the rich heritage and knowledge of the food industry and agriculture, some sort of a gastronomic seat (centre for gastronomy) could be established in the area. Perhaps the first step may be the organization of thematic conferences, round tables or events that would attract diverse knowledge and motivate people who see a wide range of opportunities in the development of gastronomy tourism, not only for the tourist and social and local environment, but also for the whole economy and rural development. Similar strategic actions have a potentially clearly defined stakeholder role in such a story; for example, caterers may be aware of the importance of supporting the local environment through the purchase of local foods, both economically and in terms of preserving cultural heritage and natural values. Professionals and public organizations work as mediators and creators of sustainable development, while the farmers and local food providers themselves should be committed to tradition and stay motivated to acquire knowledge for innovation.

Now, before Slovenia takes over the title as the European Region of Gastronomy 2021, is an ideal time to dive deeper into the tradition and cultural heritage of the rural area and the whole destination, to renew and upgrade our knowledge, as well as to strengthen the links between stakeholders in tourism and the local enviroment. Gastronomy is an excellent tool for improving the tourism offer, for developing tourism in the rural area and for recognition of the destination. Gastronomy tourism is a field for strengthening the economic and especially agricultural environment and consequently raising the quality of people's lives in the Vipava Valley.

\section{REFERENCES}

1. Ashleigh, E., Parkb, E., Sangkyun, K., \& Yeomanb, I. (2018). What is food tourism. Progress in Tourism Management, 68(1), 250-263.

2. Bessière, J. (1998). Local development and heritage: traditional food and cuisine as tourist attractions in rural areas. Sociologia Ruralis, 38(1), 21-34.

3. Björk, P., \& Kauppinen-Räisänen, H. (2014). Culinarygastronomic tourism - a search for local food Experiences. Nutrition \& Food Science, 44(4), 294-309.

4. Bogataj, J., Škufca Adelšič, D., Renko, M., Zmrzlikar, B., \& Kejžar, N. (2018). Okusiti Slovenijo: Taste Slovenia. Retrived 9. 2. 2019 from https://issuu.com/slovenia/ docs/okusiti_slovenijo_knjiga_kandidatura

5. Gačnik, A. (2012). Gastronomy heritage as a source of development for gastronomy tourism and as a means of increasing Slovenia's tourism visibility. Academia Turistica, 5(2), 39-60.

6. Gomišček, T. (2011). Nekdaj in zdaj iz loncev. In J. Slak \& M. Močivnik (Eds.), Vipavska: barve, vonji, okusi (pp. 46). Dobravlje: Revija Vino.

7. ICOMOS - Slovensko nacionalno združenje za spomenike in spomeniška območja. (2003). Doktrina 1. Ljubljana: ICOMOS - Slovensko nacionalno združenje za spomenike in spomeniška območja.

8. Merljak, M. (2016). Življenje v ravnovesju. Ljubljana: Sanjska knjiga.

9. Milfelner, B., \& Lebe, S. S. (2008). Gastronomija bistvena prvina turistovega doživljanja destinacije. Naše gospodarstvo, 54(5-6), 51-64.

10. Okumus, B., Okumus, F., \& McKercher, B. (2005). Incorporating local and international cuisins in the marketing of tourism destinations: The cases of Hong Kong and Turkey. Tourism Management, 28(1), 253261.

11. Perez-Galvez, J.C., Lopez-Guzman, T., Cordova-Buiza, F., \& Medina-Viruel, M.J. (2017). Gastronomy as an element of attraction in a tourist destination: the case of Lima, Peru. Journal of Etnic Foods, 4(4), 254-261.

12. Plahuta, S. (2002a). Prehrana na Goriškem. Nova Gorica: Goriški muzej.

13. Plahuta, S. (2002b). Jedi na Goriškem 1. Nova Gorica: Goriški muzej.

14. Strategija trajnostne rasti slovenskega turizma 2017. Republika Slovenija, Ministrstvo za gospodarski razvoj in tehnologijo 2021. Retrived 9.10.2017 from: https://www. slovenia.info/uploads/dokumenti/kljuni_dokumenti/ strategija_turiz1ma_kljucni_poudarki_koncno.pdf

15. Strategija razvoja gastronomije Slovenije. (2006). Center za interdisciplinarne in multidisciplinarne raziskave in študije, Znanstveni inštitut za regionalni razvoj pri Univerzi v Mariboru, Slovenska turistična organizacija. Retrived 22.9.2020 from https://www.slovenia.info/ uploads/dokumenti/turisticni-produkti/Strategija_ gastronomije-31.8.2006_4277_11649.pdf

16. Timothy, D. (2016). Heritage cuisines: traditions, identities and tourism. London: Routledge.

17. Timoty, D., \& Amos, S.R. (2013). Understanding heritage cusines and tourism: identity, image, authencity and change. Retrived 22.9. 2020 from https://www. academia.edu/6421922/Understanding_Heritage_ Cuisines_and_Tourism_Identity_Image_Authenticity_ and_Change?email_work_card=title

18. World Tourism Organization [UNWTO]. (2017). Second global report on gastronomy tourism. Retrived 9. 2. 2018 from http://cf.cdn.unwto.org/sites/all/files/ pdf/gastronomy_report_web.

19. UNWTO. (2015). 1st UNWTO world forum on food tourism. Retrived 22.9.2020 from https://www.unwto. org/archive/global/event/1st-unwto-world-forum-foodtourism. 


\section{Vloga kulturne dediščine pri razvoju gastronomskega turizma na podeželju: primer Vipavske doline}

\section{IZVLEČEK}

Hrana je odsev naravnih danosti, socialnega, gospodarskega in kulturnega razvoja, zaradi česar se razvijajo posebnosti v kuhinji, prehranjevanju in tehnologijah. Jedi postanejo značilno teritorialne zaradi terroirja, ki oblikuje značilnosti surovin in jedi. Pri načrtovanju ponudbe gastronomskega turizma je za zahteve sodobnega turista nujno utemeljevanje gastronomije na vsem, kar nam dajejo tako sodobni kulturni vplivi, kot tisti iz preteklosti. Raziskava se osredotoča na gastronomijo in kulinariko kot interpretacijski orodji za spoznavanje kulturne dediščine Vipavske doline. Na podlagi obstoječih teoretičnih izsledkov smo s polstrukturiranimi intervjuji s strokovnjaki iz različnih področij, povezanih z vipavsko gastronomijo ali snovno in nesnovno kulturno dediščino, raziskali potencial gastronomskega turizma in vlogo dediščine v njem. Ugotovitve intervjujev smo potrdili $\mathrm{z}$ analizo treh primerov iz lokalnega okolja. Utrditev in nadgradnja gastronomskega turizma Vipavske doline je odvisna predvsem od spodbudnega gospodarskega okolja, spoštovanja dediščine in posameznikovih inovacij. Trajnostni razvoj destinacije temelji na trdni lokalni identiteti domačinov, ki je povezan $\mathrm{z}$ bogatimi naravnimi viri in $\mathrm{z}$ dediščino pridelave in predelave lokalnih surovin. Raziskava je potrdila veliko vlogo narave pri oblikovanju kulturne dediščine podeželja.

Ključne besede: agrikultura, gastronomija, turizem, razvoj na podeželju 